\title{
Linking Plant Ecology AND LONG-TERM HYDROLOGY TO ImPROVE WeTLAND RESTORATION SuCCESS
}

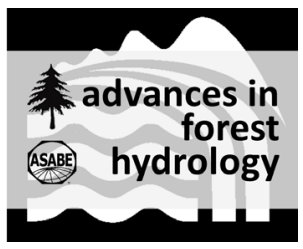

\author{
P. V. Caldwell，M. J. Vepraskas，J. D. Gregory，R. W. Skaggs， R. L. Huffman
}

\begin{abstract}
Although millions of dollars are spent restoring wetlands, failures are common, in part because the planted vegetation cannot survive in the restored hydrology. Wetland restoration would be more successful if the hydrologic requirements of wetland plant communities were known so that the most appropriate plants could be selected for the range of projected hydrology at the site. Here we describe how hydrologic models can be used to characterize the long-term hydrology of wetland plant communities, and we show how these results can be used to define wetland design criteria. In our study, we quantified differences in long-term (40-year) hydrologic characteristics of the pond pine woodland (PPW), nonriverine swamp forest (NRSF), high pocosin (HP), and bay forest $(B F)$ plant communities native to the North Carolina Coastal Plain. We found that the median water level was $8 \mathrm{~cm}$ below the land surface in $P P W$ and 9,2, and $8 \mathrm{~cm}$ above the land surface for NRSF, HP, and BF, respectively. When the land surface was inundated, the median duration of inundation was 91 d year-1 for PPW and 317, 243, and 307 d year-1 for NRSF, HP, and BF, respectively. Our models suggested that the $P P W$ received an average of $15 \%$ of its water input from groundwater inflow, whereas the other communities we modeled did not appear to receive groundwater inflow. Using these results and soil organic layer thickness, we developed and propose design criteria linking soil, vegetation, and hydrology parameters that should contribute to improved restoration success.

Keywords. Carolina Bay, Hydrologic modeling, Hydrology, Hydroperiod, Plant community, Wetland.
\end{abstract}

$\mathrm{R}$ estoration ecology manipulates altered landscapes in an attempt to speed the recovery of affected ecosystems (Dobson et al., 1997). The ecological function of the historic system is an ideal target for restoration but is likely unachievable given modern constraints and is not necessary for a restoration to be considered a success (SER, 2004). The goal of wetland restoration is to regain wetland functions by modifying the soils, hydrology, and vegetative communities of disturbed wetland sites. Hydrology is often considered the most important element of wetland restoration because it drives vegetative community composition (De Steven and Lowrance, 2011) and controls important wetland functions such as denitrification and carbon sequestration (Mitsch and Gosselink, 2007).

Through regulatory and non-regulatory wetland restoration programs, there was a net gain in wetland area of approximately 76,300 ha in the U.S. between 1998 and 2004 (Dahl,

Submitted for review in March 2011 as manuscript number SW 9146; approved for publication by the Soil \& Water Division of ASABE in November 2011.

The authors are Peter V. Caldwell, Research Hydrologist, USDA Forest Service, Eastern Forest Environmental Threat Assessment Center, Raleigh, North Carolina; Michael J. Vepraskas, W. N. Reynolds Distinguished Professor, Department of Soil Science, James D. Gregory, Professor Emeritus, Department of Forestry and Environmental Resources, R. Wayne Skaggs, ASABE Fellow, W. N. Reynolds Distinguished University Professor, Department of Biological and Agricultural Engineering, and Rodney L. Huffman, ASABE Member Engineer, Associate Professor, Department of Biological and Agricultural Engineering, North Carolina State University, Raleigh, North Carolina. Corresponding author: Peter V. Caldwell, Eastern Forest Environmental Threat Assessment Center, 920 Main Campus Drive, Suite 300, Raleigh, NC 27606; phone: 919-515-1560; e-mail: peter_caldwell@ncsu.edu.
2006). Actual wetland area restored is unknown but was greater than 76,300 ha because this figure also includes wetland lost to other land uses. Wetland restoration is expensive, and costs can vary considerably depending on land acquisition costs, the extent of alteration, the type of wetland, and the size of the site. In 2001, the USDA Wetland Reserve Program reported an average cost of wetland restoration of nearly $\$ 3000 \mathrm{ha}^{-1}$ (USDA, 2002a). A conservative estimate of spending on wetland restoration in the U.S. between 1998 and 2004 would then be nearly $\$ 230$ million for a cumulative restoration area of 76,300 ha.

Soil modifications in wetland restoration involve contouring the surface to slow water runoff, while hydrologic modifications (e.g., ditch filling) raise the water table and lengthen periods of saturation. Vegetative modifications generally include targeting specific wetland plant communities and then planting species typical of those communities at the restoration site. Restoration projects are considered failures by environmental regulators when the restored plant communities either do not survive or are overtaken by plants creating different plant communities than those targeted for restoration. Return of wetland functions such as denitrification or carbon sequestration are not considered when assessing restoration success for regulatory purposes because they are difficult to assess quickly, whereas the survival of vegetation is obvious through on-site inspection. Restoration failures usually occur because the planted vegetation is not well adapted to the restored hydrology at a given location on the site (Dennison and Schmid, 1997). To increase the probability that at least some vegetation survives, wetland designers frequently plant a variety of vegetation at a restoration site with a range of hydrologic requirements (Morgan and Roberts, 2003). While this hit-or-miss practice is effective in some cases, it is inefficient, 
offers no guarantee of success, and delays restoration of the functions provided by the target wetland plant community. Designing wetlands where hydrology matches the target wetland community in terms of the average depth of the water table, frequency and duration of inundation, etc., would improve restoration efficiency by closely matching the hydrology to the needs of the target vegetation. However, quantitative data describing the hydrologic needs of most wetland plant communities are scarce in literature (Zedler, 2000).

Pond pine woodland (PPW), nonriverine swamp forest (NRSF), high pocosin (HP), and bay forest (BF) are examples of wetland plant communities commonly found along the Atlantic Coastal Plain of North America (Schafale and Weakley, 1990). Differences in dominant species, size, and density of the canopy and shrub layers distinguish one plant community from another (table 1). Environmental factors believed to affect the establishment of these communities include the thickness of organic soil layers, fire frequency and intensity, plant-available phosphorus in the soil, hydrology, and disturbance history (Sharitz and Gibbons, 1982; Dimick et al., 2010). While the relative contributions of these factors on plant community succession and establishment are codependent and difficult to distinguish and quantify (Richardson, 2003; Levin, 1992), hydrology is considered a major influence on the relative contributions of the other factors (De Steven and Toner, 2004; Kirkman et al., 2000). For example, inundation (when water is above the land surface) affects the survival and growth of wetland plant species and influences the spatial distributions of plant communities across the landscape (Megonigal and Day, 1992). Inundation during wet years (e.g., 90th percentile hydroperiods) has been shown to influence species composition in forested riverine wetlands (Townsend, 2001). Even if a particular site is rarely inundated, soil saturation can influence the vegetative community because some wetland plant species do not extend roots below the water table. Others that do will develop deeper root systems when growing in periodically flooded soils compared to continuously flooded conditions (Megonigal and Day, 1992; Schwintzer and Lancelle, 1983). Deeper root systems may provide access to mineral soil layers of higher plant-available nutrient content that lie below the organic surface layers of lower plant-available nutrient content during drier periods, which may result in plant communities of larger stature, such as PPW and NRSF (Schafale and Weakley, 1990; Townsend, 2001; Otte, 1982). Communities with larger trees (PPW and NRSF) may also receive an influx of groundwater carrying dissolved nutrients into these communities (Schafale and Weakley, 1990; Otte, 1982).

Most of the hydrologic requirements for wetland plant communities described in the literature use semi-quantitative terms such as "seasonally or frequently flooded or ponded to the surface" to characterize hydrology (Schafale and Weakley, 1990) because long-term studies were not conducted. More quantitative data would enable wetlands to be designed to match the hydrologic requirements of natural plant communities. The few studies that have attempted to quantify the hydrology of wetland plant communities did so over a short period of time (e.g., less than three years), taking little account of year-to-year variability in weather patterns that strongly affect long-term hydrology and vegetative growth in a wetland ecosystem. For example, Johnson et al. (2011) collected water table depths at several wetland sites in eastern North Carolina over a seven-month period to examine
Table 1. Typical characteristics of pond pine woodland (PPW), nonriverine swamp forest (NRSF), high pocosin (HP), and bay forest (BF) plant communities.

\begin{tabular}{lccc}
\hline & $\begin{array}{c}\text { Canopy } \\
\text { Deight }[\mathrm{b}] \\
(\mathrm{m})\end{array}$ & $\begin{array}{c}\text { Basal } \\
\left.\mathrm{Area}^{[\mathrm{c}]}\right] \\
\left(\mathrm{m}^{2} \mathrm{ha}^{-1}\right)\end{array}$ & $\begin{array}{c}\text { Surface } \\
\text { Layer }[\mathrm{d}] \\
(\mathrm{cm})\end{array}$ \\
\hline $\begin{array}{l}\text { Pond pine woodland (PPW) } \\
\quad \text { Pinus serotina (pond pine) }\end{array}$ & 18 & 12.4 & $>40$ \\
\hline $\begin{array}{l}\text { Nonriverine swamp forest (NRSF) } \\
\text { Taxodium distichum (bald cypress) }\end{array}$ & 25 & 22.3 & 20 to 80 \\
$\quad \begin{array}{l}\text { Taxodium ascendens (pond cypress) } \\
\text { Nyssa biflora (swamp tupelo) }\end{array}$ & & & \\
\hline High pocosin (HP) & 7.6 & 1.9 & $>80$ \\
$\quad \begin{array}{l}\text { Pinus serotina (pond pine) } \\
\text { Gordonia lasianthus (loblolly bay) }\end{array}$ & & & \\
$\quad \begin{array}{l}\text { Persia palustris (red bay) } \\
\text { Magnolia virginiana (sweet bay) }\end{array}$ & & & \\
\hline $\begin{array}{l}\text { Bay forest (BF) } \\
\text { Gordonia lasianthus (loblolly bay) }\end{array}$ & & & \\
$\quad \begin{array}{l}\text { Persia palustris (red bay) } \\
\text { Magnolia virginiana (sweet bay) }\end{array}$ & & & \\
\hline
\end{tabular}

[a] Source: Schafale and Weakley (1990).

[b] Source: Otte (1982) and Hall and Penfound (1939).

[c] Source: Dimick et al. (2010).

[d] Thickness of surface organic soil layer (Dimick et al., 2010).

whether hydrology may explain the presence of three wetland plant community types, including NRSF. The ideal study would evaluate plant community hydrology based on long-term (e.g., 40 years or more) field observations of undisturbed sites, but these data for any given location are scarce because compiling them requires a significant time investment.

In the absence of long-term observational studies, computer models that are calibrated for a specific site can provide quantitative long-term data describing wetland plant community hydrology with acceptable levels of accuracy using historic weather data as model input (Beven, 2001). For example, plans to restore the Florida everglades were based on extensive modeling of historical hydrology (Zedler, 2000; DeAngelis et al., 1998). We have tested site-calibrated models of wetland hydrology against in situ measurements and found that they were effective in predicting daily water levels (He et al., 2002; Caldwell et al., 2007).

Here we describe the use of hydrologic models to quantify the long-term hydrology of wetland plant communities, and we provide recommendations for the restoration of these communities. We calibrated hydrologic computer models for sites supporting four wetland plant communities and simulated the long-term hydrology of each plant community using a 40-year historical weather record. Our objectives were: (1) to quantify the long-term hydrologic conditions of four common plant communities in reference wetlands of the Atlantic Coastal Plain of North America, and (2) to link the critical characteristics of hydrology and soils that are needed for wetland restoration site design and selection of plant species.

\section{Methods}

\section{SiTE DESCRIPTIONS}

Our study sites included Charlie Long Millpond Bay (204 ha), Tatum Millpond Bay (808 ha), and Causeway Bay (145 ha) located on the Coastal Plain of North Carolina (fig. 1). The sites are at approximately $34^{\circ} 40^{\prime} 59^{\prime \prime} \mathrm{N}$ and $78^{\circ}$ $34^{\prime} 54^{\prime \prime} \mathrm{W}$ in the vicinity of the Bladen Lakes State Forest, with an average air temperature of $16.8^{\circ} \mathrm{C}$ and average annu- 


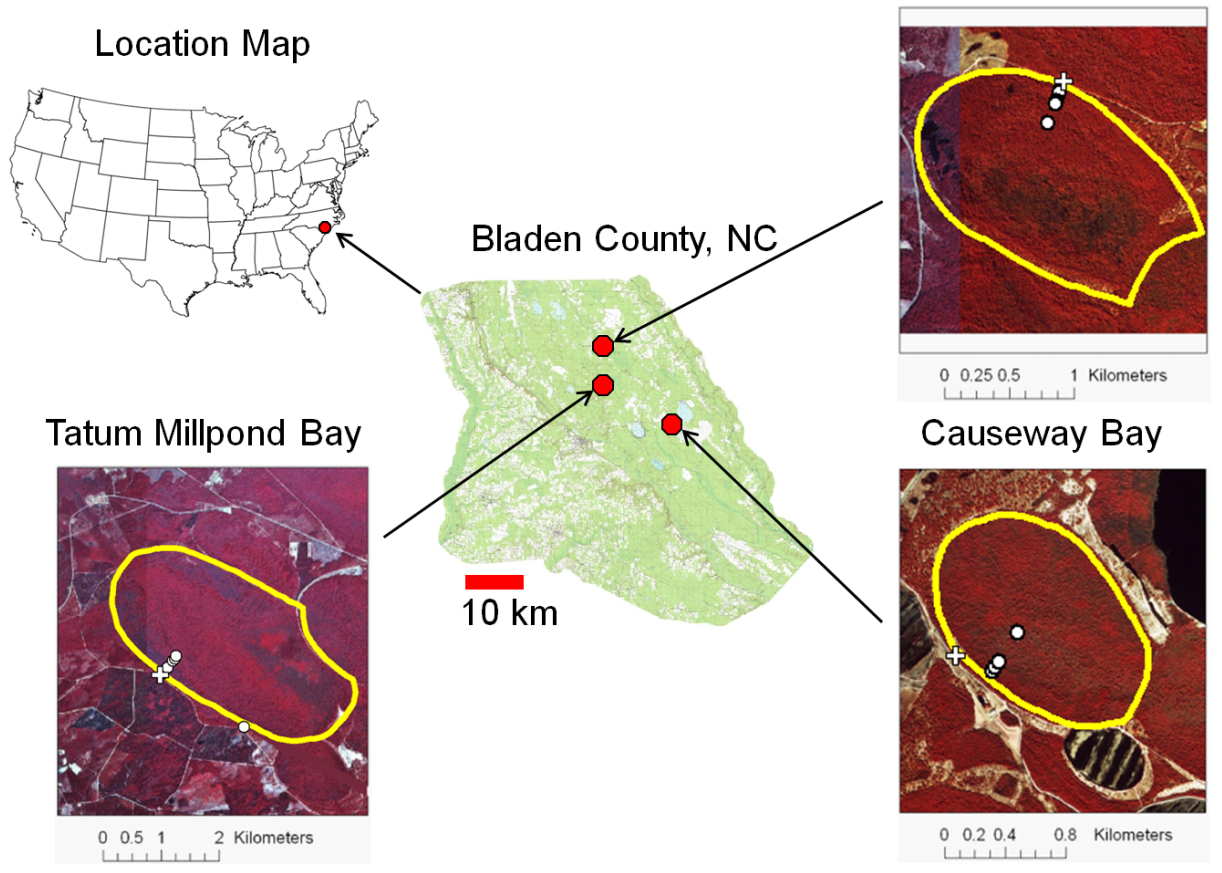

Figure 1. Locations and boundaries of Carolina Bay wetland sites. Approximate locations of the water level recording wells and rain gauges are represented by the white circles and white crosses, respectively.

al rainfall of $123 \mathrm{~cm}$ (USDA, 2002b). Soils types in the study sites typically transition from mostly mineral composition nearest the bay perimeter to mostly organic composition in the center. Torhunta (coarse-loamy, siliceous, active, acid, thermic, Typic Humaquepts), Lynn Haven (sandy, siliceous, thermic, Typic Alaquods), and Leon (sandy, siliceous, thermic, Aeric Alaquods) soil series are found along the perimeter (Leab, 1990). Meanwhile, Pamlico (sandy or sandyskeletal, siliceous, dysic, thermic, Terric Haplosaprists) and Croatan (loamy, siliceous, dysic, thermic, Terric Haplosaprists) soil series can be found near the centers of the bays (Leab, 1990). Soil textures of the mineral horizons include sandy loam, loamy sand, and sand.

Both Tatum Millpond Bay and Charlie Long Millpond Bay have been managed by the North Carolina Division of Forest Resources since 1938 and have not been extensively burned in the last 65 to 70 years (Ewing, 2003). Tatum Millpond Bay was selectively logged for Atlantic white cedar between 1938 and 1954 (Dimick et al., 2010). Charlie Long Millpond Bay reportedly has never been logged, although it was used to practice fireline construction in the 1970s (Ewing, 2003). Causeway Bay is privately owned and also has not been burned in the last 65 to 70 years. Past management practices in Causeway Bay are unclear, but it is known that the last timber harvest occurred on the northeast end in the 1960s (Ewing, 2003). Since the sites had not been significantly altered with artificial drainage, and vegetative communities had not been disturbed in at least 65 years, we considered them to closely represent reference conditions for these plant communities.

\section{Plant Community Assessment}

Assessment of plant community distribution at our study sites was detailed by Dimick et al. (2010). Access trails (straight line transects) were established roughly along the minor axes of the bays and extended from the perimeter to the center for a distance of 300 to $460 \mathrm{~m}$ (fig. 2). Along each transect, 15 to 20 plots $(5 \mathrm{~m} \times 5 \mathrm{~m})$ were established approximately every $30 \mathrm{~m}$ for soil and vegetation classification. In each of the bays, PPW was generally found nearest the edge, while HP was near the center. Tatum Millpond Bay also supported NRSF and BF communities.

\section{Hydrologic Model Development}

Water level recording wells (WL-40 Series, Remote Data Systems, Inc., Navassa, N.C.) were installed to a depth of $1 \mathrm{~m}$ in each of 15 of the vegetation plots (four to seven plots at each site). In all, wells were installed in six, three, four, and two plots in the PPW, NRSF, HP, and BF communities, respectively (fig. 2). Hourly water table depths were recorded and summarized on a daily basis over a two-year period from April 2003 to May 2005 for model calibration. One tippingbucket rain gauge (Rain Collector II, Davis Instruments, Hayward, Cal.) was installed near the perimeter of each of the three sites to estimate hourly rainfall for all plots in a given site. Estimates of daily Penman-Monteith potential evapotranspiration were calculated using air temperature, relative humidity, wind speed, solar radiation, and barometric pressure measured at the North Carolina Division of Forest Resources' Turnbull Creek weather station in Bladen Lakes State Forest, located 5 to $15 \mathrm{~km}$ from the three study sites. Soil saturated hydraulic conductivity was measured in situ using the piezometer method (Luthin and Kirkham, 1949), and soil water characteristic data were generated from intact cores collected from each plot using a pressure cell apparatus (Klute, 1986). These data were used as input for DRAINMOD hydrologic models for each well location (Skaggs, 1978). DRAINMOD has been used extensively for optimizing drainage systems for agricultural land uses, but it has also been used to simulate the hydrology of natural, undrained 

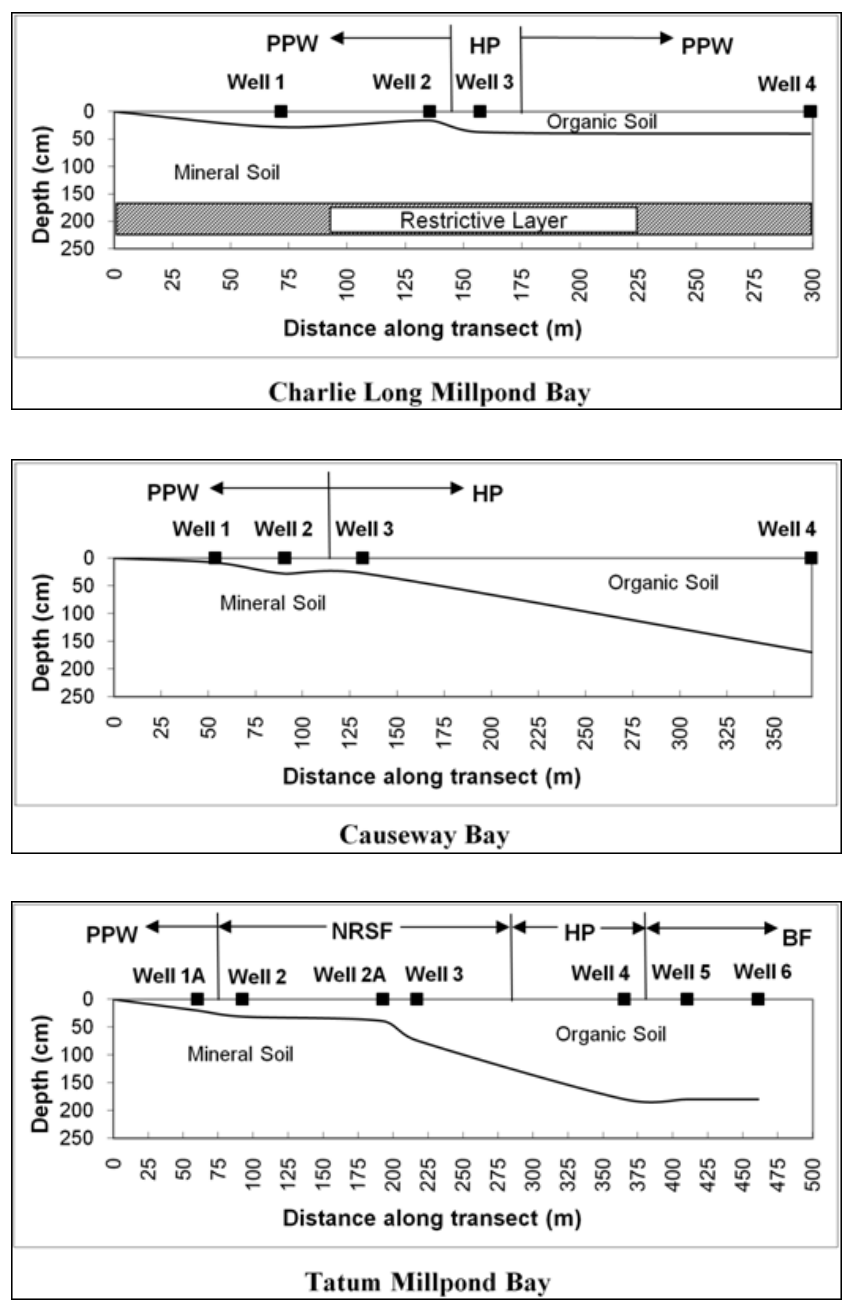

Figure 2. Water level recording wells at pond pine woodland (PPW), nonriverine swamp forest (NRSF), high pocosin (HP), and bay forest community locations and approximate depths of organic soil layers along each transect. Transect lengths vary by site. Relative surface elevations along transects are not represented.

wetlands such as Carolina bays (He et al., 2002; Chescheir et al., 1994, 2008).

DRAINMOD is a hydrologic modeling package originally developed to simulate agricultural drainage systems in poorly drained soils, such as those of the Coastal Plain of North Carolina. The model assumes a network of parallel drainage ditches or drain tiles at a given depth and spacing above a restrictive layer (fig. 3). No such drainage system existed at the natural Carolina bays in this study. The drain spacing $(L)$, drain depth $(b)$, and surface storage $(s)$ were treated as calibration parameters without specific physical definition. Adjusting these parameters changes the nature of the relationship between the drainage rate and the water table depth, approximating the relationship that naturally existed at the wetland sites. A confined artesian aquifer provided a source of groundwater inflow for some plots. In those cases, the conductivity of the confining clay layer was an additional variable adjusted for model calibration. The pressure head measured in the confined aquifer was simulated with an empirical model based on rainfall and evapotranspiration.

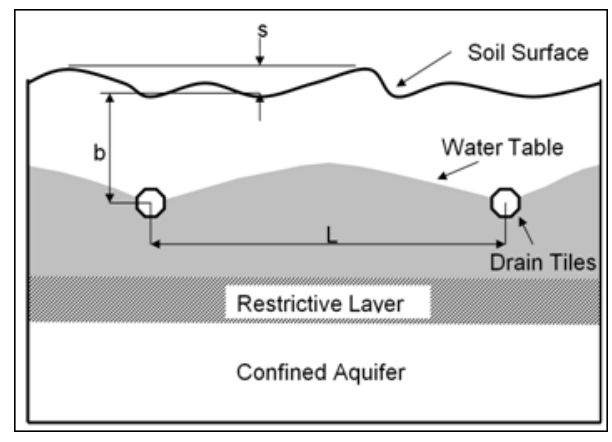

Figure 3. Schematic of the drainage system simulated by DRAINMOD. Parameters adjusted in the model calibration process included the drain depth $(b)$, drain spacing $(L)$, and surface storage $(s)$.

A complete description of the model calibration may be found in Caldwell et al. (2007) and is summarized here. The 15 models (one model for each plot) were calibrated by adjusting $b, L$, and $s$ (fig. 3 ) such that the average absolute difference between simulated and measured water table depths over the two-year calibration period was minimized. The models were calibrated by first assuming a drain depth and surface storage depth. The drain spacing was iterated until the average absolute deviation between predicted and observed water table depth was minimized. This process was repeated for the other drainage system parameters, iterating the drain depth next and the surface storage depth last. For sites where groundwater inflow from the semi-confined aquifer was significant, the vertical saturated hydraulic conductivity of the restrictive layer was iterated in conjunction with each of these variables. After model calibration, historical weather data collected in Fayetteville, North Carolina, from 1964 to 2004 (40 years) were used as input for the models to simulate the long-term hydrology for each plot. Fayetteville is located approximately $50 \mathrm{~km}$ from the study sites.

In addition to calibration, hydrologic models are sometimes validated using observed measurements that do not overlap with the data used for model calibration. In this study, we were limited to two years of observed data; thus, we elected to use the entire dataset for model calibration so that a broader range of weather variability would be covered in the calibration process. This approach has been used successfully to calibrate DRAINMOD models at similar wetland sites (He et al., 2002). Validation of the DRAINMOD model in general has been discussed extensively in the literature (e.g., Skaggs et al., 1981; Skaggs, 1982; Workman and Skaggs, 1989; Broadhead and Skaggs, 1989).

\section{Data Analysis}

All statistical analyses were performed using JMP 8.0 (SAS, 2008). For each location, the long-term water level cumulative frequency distribution and other statistics describing hydrologic characteristics of the plant communities were computed based on daily water table depths predicted by the hydrologic models over the 40-year simulation. Mean hydrologic characteristics from all locations supporting a given plant community were computed to represent that community. Differences between mean hydrologic characteristics of each plant community were assessed in ANOVA using the Tukey-Kramer honest significant difference (HSD) evaluated at $\alpha=0.05$. 
Table 2. Average absolute deviations between predicted and observed water table depths at plot locations representing pond pine woodland (PPW), nonriverine swamp forest (NRSF), high pocosin (HP), and bay forest (BF) plant communities, and the DRAINMOD model drainage system parameters resulting from calibration process (adapted from Caldwell et al., 2007).

\begin{tabular}{|c|c|c|c|c|c|c|c|c|c|}
\hline Site & $\begin{array}{c}\text { Well } \\
\text { Location }\end{array}$ & $\begin{array}{c}\text { Plant } \\
\text { Community }\end{array}$ & $\begin{array}{c}\text { Average } \\
\text { Absolute } \\
\text { Deviation } \\
(\mathrm{cm})\end{array}$ & $\begin{array}{l}\text { Drain } \\
\text { Depth } \\
(b, \mathrm{~cm})\end{array}$ & $\begin{array}{c}\text { Drain } \\
\text { Spacing } \\
(L, \mathrm{~cm})\end{array}$ & $\begin{array}{l}\text { Surface } \\
\text { Storage } \\
(s, \mathrm{~cm})\end{array}$ & $\begin{array}{l}\text { Depth to } \\
\text { Restrictive } \\
\text { Layer } \\
\text { (cm) }\end{array}$ & $\begin{array}{c}\text { Restrictive } \\
\text { Layer } \\
\text { Thickness } \\
(\mathrm{cm})\end{array}$ & $\begin{array}{c}\text { Restrictive } \\
\text { Layer } \\
\text { Conductivity } \\
\left(\mathrm{cm} \mathrm{h}^{-1}\right)\end{array}$ \\
\hline \multirow{4}{*}{$\begin{array}{l}\text { Charlie } \\
\text { Long } \\
\text { Millpond }\end{array}$} & 1 & PPW & 4.1 & 5 & 13000 & 4.5 & 170 & 55 & 0.00058 \\
\hline & 2 & PPW & 3.3 & 85 & 10000 & 1.1 & 170 & 55 & 0.0044 \\
\hline & 3 & HP & 4.9 & 95 & 5500 & 2.0 & 183 & 112 & 0.0098 \\
\hline & 4 & PPW & 6.1 & 65 & 3150 & 0.7 & 170 & 55 & 0.0029 \\
\hline \multirow{4}{*}{$\begin{array}{c}\text { Causeway } \\
\text { Bay }\end{array}$} & 1 & PPW & 4.3 & 20 & 3500 & 0.1 & 170 & 55 & 0.0013 \\
\hline & 2 & PPW & 1.5 & 10 & 999999 & 4.2 & 170 & $\mathrm{ND}^{[\mathrm{a}]}$ & ND \\
\hline & 3 & $\mathrm{HP}$ & 0.5 & 45 & 440000 & 7.25 & 170 & ND & ND \\
\hline & 4 & HP & 0.9 & 40 & 999999 & 6.1 & 170 & ND & ND \\
\hline \multirow{7}{*}{$\begin{array}{l}\text { Tatum } \\
\text { Millpond } \\
\text { Bay }\end{array}$} & $1 \mathrm{~A}$ & PPW & 5.5 & 55 & 9000 & 0.1 & 170 & 55 & 0.0028 \\
\hline & 2 & NRSF & 0.3 & 70 & 334000 & 15 & 170 & ND & ND \\
\hline & $2 \mathrm{~A}$ & NRSF & 1.1 & 65 & 107000 & 14 & 170 & ND & ND \\
\hline & 3 & NRSF & 0.2 & 65 & 496500 & 16 & 170 & ND & ND \\
\hline & 4 & HP & 0.7 & 55 & 150000 & 16 & 170 & ND & ND \\
\hline & 5 & $\mathrm{BF}$ & 1.4 & 55 & 355000 & 12 & 170 & ND & ND \\
\hline & 6 & $\mathrm{BF}$ & 0.4 & 55 & 90400 & 14 & 170 & ND & ND \\
\hline
\end{tabular}

[a] $\mathrm{ND}=$ not determined. No groundwater inflow required to calibrate these models.

\section{RESUlTS AND DisCuSSION}

\section{Model Calibration}

Average absolute deviations between predicted and observed water table depths for the 15 DRAINMOD models of well locations in the study sites were quite low, averaging approximately $4 \mathrm{~cm}$ (table 2). These low deviations were partly due to the very shallow water table depths observed over the calibration period, which served to minimize deviations between simulated and measured data (Caldwell et al., 2007). The shallow drain depth (e.g., $10 \mathrm{~cm}$ ) and/or wide drain spacing (e.g., 999,999 cm) of the calibrated DRAINMOD parameters reflect the low natural subsurface drainage rates of these sites. Surface storage parameters obtained through calibration were relatively high, a result of the high variability of soil surface elevation. Overall, the simulated water table depths correlated very well with those measured at the study sites, providing us with good confidence in the ability of the models to predict water table depths at these sites.

\section{WATER BALANCE}

Evapotranspiration (ET) was the largest water loss component (table 3). On average, annual ET amounted to $64 \%$ of the annual total precipitation. Average annual surface runoff was similar between PPW and NRSF, slightly higher for BF, and greater still for HP. This is likely due to the relative elevations of the different plant communities. HP and BF occur on deep organic soils, which potentially accumulate organic materials such that the soil surface is elevated relative to surrounding areas (Daniels et al., 1999). As a result, higher surface runoff will occur in these communities. Although surface runoff was similar between PPW and NRSF, the relatively low runoff in these communities occurred for different reasons. The water level rarely rose above the soil surface in PPW, so the majority of the rainfall was able to infiltrate the soil rather than running off. The water level was generally above the soil surface in NRSF, but the greater surface storage of NRSF (15 cm mean across three NRSF plots) versus PPW (1.8 cm mean across six PPW plots) allowed excess rainfall to be stored on the surface instead of running off (Caldwell et al., 2007).

The PPW plant community received approximately $15 \%$ of its average annual water input from groundwater inflow, while the other communities did not receive groundwater inflow. Groundwater outflow in PPW exceeded inflow on an annual basis, but during dry periods groundwater inflow exceeded outflow, helping to keep water levels generally within $30 \mathrm{~cm}$ of the surface at some sites even during years of low rainfall (fig. 4). Net drainage (groundwater outflow minus groundwater inflow) for PPW was similar to the groundwater outflow of NRSF. HP and BF had lower annual drainage amounts because of the additional water lost as surface runoff in these communities. Runoff from pocosins occurs as sheet flow over broad stretches rather than streams or ditches (Ash et al., 1983). As a result, the surface runoff component of the water balance may have actually been lost from the system below the soil surface. Sheet flow occurs just below the litter layer, following small but relatively discrete channels. Analysis of the plant nutrients in the soils of these sites showed that the litter layers (Oi horizon) contain most of the plantavailable $\mathrm{P}, \mathrm{K}, \mathrm{Ca}$, and $\mathrm{Mg}$, as well as total $\mathrm{N}$ in the soils (Ewing et al., 2011). Water moving through this litter layer would leach some of these nutrients laterally into adjacent soils. The surface runoff from the HP community may have contributed to the groundwater inflow component of adjacent PPW plant communities. These results suggest that the notion proposed

Table 3. Simulated long-term average annual water balance components for the pond pine woodland (PPW), nonriverine swamp forest (NRSF), high pocosin (HP), and bay forest (BF) plant communities. Average annual rainfall and ET for all plant communities were 118 and $76 \mathrm{~cm}$, respectively.

\begin{tabular}{ccccc}
\hline $\begin{array}{c}\text { Plant } \\
\text { Community }\end{array}$ & $\begin{array}{c}\text { No. of } \\
\text { Plots }\end{array}$ & $\begin{array}{c}\text { Surface } \\
\text { Runoff } \\
(\mathrm{cm})\end{array}$ & $\begin{array}{c}\text { Groundwater } \\
\text { Outflow } \\
(\mathrm{cm})\end{array}$ & $\begin{array}{c}\text { Groundwater } \\
\text { Inflow } \\
(\mathrm{cm})\end{array}$ \\
\hline PPW & 6 & $20 \pm 5.5$ & $43 \pm 10.6$ & $21 \pm 7.5$ \\
NRSF & 3 & $20 \pm 0.7$ & $22 \pm 0.8$ & $0.0 \pm 0.0$ \\
HP & 4 & $30 \pm 5.4$ & $12 \pm 5.4$ & $0.0 \pm 0.0$ \\
BF & 2 & $22 \pm 0.5$ & $20 \pm 0.5$ & $0.0 \pm 0.0$ \\
\hline
\end{tabular}




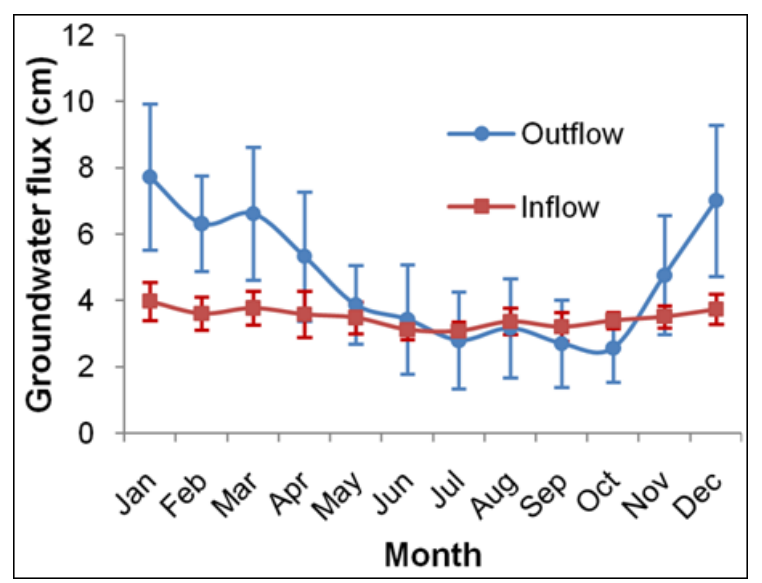

Figure 4. Simulated monthly means and standard deviations (error bars) of groundwater inflows and outflows at well 2 in Charlie Long Millpond Bay, a site supporting the pond pine woodland (PPW) community, in years with annual precipitation less than 25 th percentile levels over the 40 -year simulation period.

by Schafale and Weakley (1990) and Otte (1982) that PPW may feature larger trees than other communities due to an influx of plant-available nutrients in groundwater is plausible. There was no evidence of an influx of groundwater in the NRSF we studied, so this hypothesis cannot account for the large trees in this community.

\section{Frequency Distribution of Water TABle Depth}

Modeling results indicated that the water level was above the land surface $(>0 \mathrm{~cm}) 0 \%$ to $67 \%$ of the time over 40 -year model simulation period across sites supporting PPW (mean $24 \%$ of the time, $n=6$ sites), while it was above the surface $79 \%$ to $86 \%$ (mean $83 \%, n=3$ sites), $14 \%$ to $85 \%$ (mean $62 \%$, $n=4$ sites), and $78 \%$ to $83 \%$ (mean $80 \%, n=2$ sites) of the time across sites supporting NRSF, HP, and BF, respectively (fig. 5). When water was above the land surface, it reached a maximum depth of 14 to $16 \mathrm{~cm}$ (mean $15 \mathrm{~cm}), 1$ to $16 \mathrm{~cm}$ (mean $8 \mathrm{~cm}$ ), and 12 to $14 \mathrm{~cm}$ (mean $13 \mathrm{~cm}$ ) above the surface across sites supporting NRSF, HP, and BF, respectively, and less than $4 \mathrm{~cm}$ (mean $1 \mathrm{~cm}$ ) across sites supporting PPW (fig. 5 , table 4). Using the Tukey-Kramer HSD evaluated at $\alpha=$ 0.05 , the maximum water depth above the land surface for PPW was found to be significantly different from NRSF and BF, while HP was not significantly different from the other communities. Water levels above the land surface do not indicate that the entire area is completely flooded. At our study sites, the hummocky land surface varied in elevation by $15 \mathrm{~cm}$ or more on a local scale due to the microtopography of natural hummocks and swales. These surface undulations appeared to be similar among the plant communities. Typi-

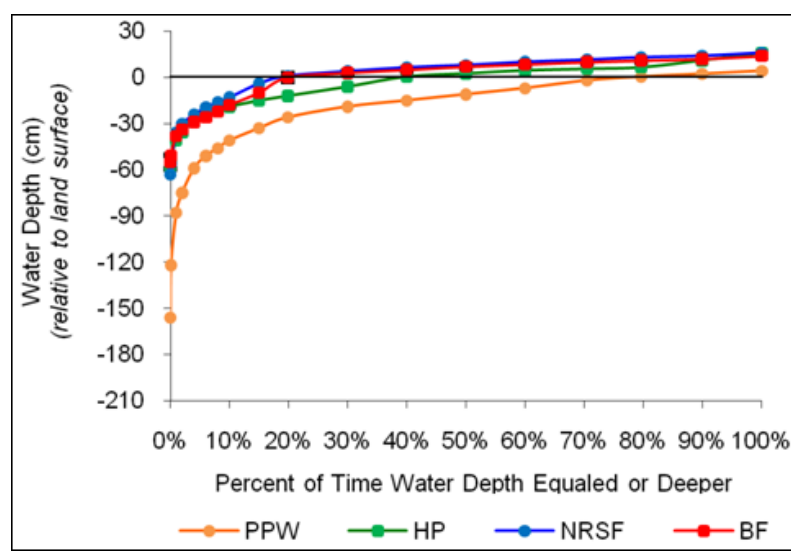

Figure 5. Daily water depth cumulative frequency distributions for the pond pine woodland (PPW), nonriverine swamp forest (NRSF), high pocosin (HP), and bay forest (BF) study sites over the 40-year simulation. Data for each plant community are averaged among the sites supporting that plant community. Water levels are shown relative to the land surface. Positive water levels indicate times when the water level was above the land surface, while negative depths are when the water level was below the surface.

cally, the local high elevations were occupied by trees and were above the levels of ponded water. The water levels we present here are measured relative to the land surface in the local low elevations. The deepest water level predicted across sites supporting PPW was 71 to $155 \mathrm{~cm}$ (mean $103 \mathrm{~cm}$ ) below the land surface, significantly different from sites supporting NRSF, HP, and BF. which had deepest water table depths of 47 to $62 \mathrm{~cm}$ (mean $55 \mathrm{~cm}$ ), 33 to $58 \mathrm{~cm}$ (mean $47 \mathrm{~cm}$ ), and 46 to 55 (mean $50 \mathrm{~cm}$ ) below the land surface, respectively. The median water level across sites supporting PPW ranged from $20 \mathrm{~cm}$ below to $2 \mathrm{~cm}$ above the surface (mean $8 \mathrm{~cm}$ below the surface), which was significantly different from sites supporting NRSF, with a median water level of 7 to $10 \mathrm{~cm}$ above the surface (mean $9 \mathrm{~cm}$ above the surface). Median water levels of $9 \mathrm{~cm}$ below to $10 \mathrm{~cm}$ above the surface (mean $2 \mathrm{~cm}$ above the surface) and $6 \mathrm{~cm}$ to $9 \mathrm{~cm}$ above the surface (mean $8 \mathrm{~cm}$ above the surface) across sites supporting HP and BF, respectively, were not significantly different from either PPW or NRSF.

\section{HYDROPERIOD}

We evaluated hydroperiod both as the total number of days of inundation per water year, a period that may or may not be continuously inundated, and as the number of consecutive days of inundation per water year (table 4). The water year was defined as a period that begins in October and ends in September of the following year, allowing continuous periods of inundation to be included in a single year, rather than

\begin{tabular}{|c|c|c|c|c|c|c|c|c|}
\hline $\begin{array}{c}\text { Plant } \\
\text { Community }\end{array}$ & $\begin{array}{l}\text { Plots } \\
(n)\end{array}$ & $\begin{array}{c}\text { Median } \\
\text { Water } \\
\text { Level } \\
(\mathrm{cm})\end{array}$ & $\begin{array}{l}\text { Minimum } \\
\text { Water } \\
\text { Level } \\
(\mathrm{cm})\end{array}$ & $\begin{array}{l}\text { Maximum } \\
\text { Water } \\
\text { Level } \\
(\mathrm{cm})\end{array}$ & $\begin{array}{c}\text { Median } \\
\text { Total } \\
\text { Hydroperiod } \\
\left(\text { d year-1) }^{-1}\right)\end{array}$ & $\begin{array}{c}\text { 90th Percentile } \\
\text { Total } \\
\text { Hydroperiod } \\
\text { (d year-1) }\end{array}$ & $\begin{array}{c}\text { Median } \\
\text { Consecutive } \\
\text { Hydroperiod } \\
(\text { d year-1) }\end{array}$ & $\begin{array}{l}\text { 90th Percentile } \\
\text { Consecutive } \\
\text { Hydroperiod } \\
(\text { d year-1) }\end{array}$ \\
\hline PPW & 6 & $-8.0 \pm 3.0 \mathrm{~b}$ & $-103.2 \pm 8.2 b$ & $1.2 \pm 1.5 \mathrm{~b}$ & $91 \pm 39 b$ & $117 \pm 45 b$ & $52 \pm 32 b$ & $73 \pm 43 b$ \\
\hline NRSF & 3 & $8.7 \pm 4.3 \mathrm{a}$ & $-54.8 \pm 11.6 \mathrm{a}$ & $15.0 \pm 2.1 \mathrm{a}$ & $317 \pm 55 \mathrm{a}$ & $361 \pm 63 \mathrm{a}$ & $271 \pm 45 \mathrm{a}$ & $353 \pm 61 \mathrm{a}$ \\
\hline HP & 4 & $2.2 \pm 3.7 \mathrm{ab}$ & $-46.8 \pm 10.1 \mathrm{a}$ & $7.7 \pm 1.8 \mathrm{ab}$ & $243 \pm 47 \mathrm{ab}$ & $293 \pm 55 \mathrm{ab}$ & $182 \pm 39 a b$ & $252 \pm 53 \mathrm{ab}$ \\
\hline $\mathrm{BF}$ & 2 & $7.5 \pm 5.3 \mathrm{ab}$ & $-50.2 \pm 14.3 \mathrm{a}$ & $13.0 \pm 2.6 \mathrm{a}$ & $307 \pm 67 \mathrm{ab}$ & $356 \pm 78 \mathrm{ab}$ & $253 \pm 56 a$ & $344 \pm 75 \mathrm{a}$ \\
\hline
\end{tabular}

[a] Values in the same column followed by the same letter are not a significantly different using the Tukey-Kramer HSD test at $\alpha=0.05$. 
split between two consecutive years. Using the TukeyKramer HSD evaluated at $\alpha=0.05$, the median total hydroperiod for PPW (91 d year-1) was significantly different from the median total hydroperiod of NRSF (317 $d$ year $\left.{ }^{-1}\right)$. The median total hydroperiod for HP (243 d year-1) and BF (307 d

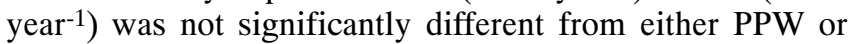
NRSF. Similarly, the total hydroperiod during wet years (i.e., 90th percentile) for PPW (117 $\left.\mathrm{d} \mathrm{year}^{-1}\right)$ was significantly different from that of NRSF (361 d year $\left.{ }^{-1}\right)$, while that of HP (293 d year ${ }^{-1}$ ) and BF (356 d year $\left.{ }^{-1}\right)$ were not significantly different from PPW or NRSF. We found significant differences between the median consecutive hydroperiod of PPW (52 d year $^{-1}$ ) compared to NRSF (271 $\left.\mathrm{d}_{\text {year }}{ }^{-1}\right)$ and BF (253 d year $\left.^{-1}\right)$, while the median consecutive hydroperiod of HP (182 d year ${ }^{-1}$ ) was not significantly different from NRSF, PPW, or BF. The 90th percentile hydroperiod for PPW (73 d year $^{-1}$ ) was significantly different from NRSF (353 d year-1) and BF (344 d year $\left.{ }^{-1}\right)$, while that of HP (252 d year $\left.{ }^{-1}\right)$ was not significantly different from the other communities. During times of high rainfall, some continuous hydroperiods lasted longer than a single water year.

\section{Design CRITERia for Restoration OF Wetland Plant Communities}

To illustrate how hydrologic modeling can be used to characterize the requirements of the wetland plant communities we studied, we propose in table 5 recommendations for establishment of these plant communities at a restoration site. Recognizing that soil organic layer thickness has been shown to be a contributing factor in the position of plant communities on the landscape (Sharitz and Gibbons, 1982; Dimick et al., 2010), we included organic layer thickness as a factor in defining these relationships. To use the recommendations for a wetland restoration, an initial site reconnaissance visit would be conducted to record the thickness of organic soil layers, install one rain gauge at a representative location on the restoration site, and install water level recording wells in at least three locations for each range of organic soil layer thickness (table 5) found on the site. Hourly rainfall and daily water table elevations would be recorded over a period of at least one year for the calibration of hydrologic models. Once the models were calibrated, they would be used to simulate the long-term hydrology at various locations after the restoration. The models could be used to determine how to prepare the site to achieve the required hydroperiod for a particular plant community or to select the most appropriate plant community that fits the expected hydrologic conditions. For portions of a wetland restoration site where the organic soil layer is less than $40 \mathrm{~cm}$ thick and the median hydroperiod estimated by hydrologic simulation is approximately 90 days per water year, PPW would be a good candidate for restoration, and tree species typical of that community should be planted there. For portions of restoration sites with organic soil layers between approximately 40 and $80 \mathrm{~cm}$ thick and median hydroperiod of approximately 310 days per water year, NRSF would be a good choice for restoration. For sites with hydroperiods of approximately 310 days per water year and organic layer thickness greater than $80 \mathrm{~cm}, \mathrm{BF}$ would be recommended.

The proposed wetland design criteria reflect the results of this study alone and should be field tested before use in largescale restoration projects. These specific recommendations should be applicable to the soil and climate conditions of the
Table 5. Recommendations for the establishment of pond pine woodland (PPW), nonriverine swamp forest (NRSF), and bay forest (BF) communities based on site characteristics.

\begin{tabular}{ccc}
\hline $\begin{array}{c}\text { Thickness of } \\
\text { Organic Soil Layer } \\
(\mathrm{cm})\end{array}$ & $\begin{array}{c}\text { Median Hydroperiod } \\
\text { (total days inundated }^{\text {per water year) }}\end{array}$ & $\begin{array}{c}\text { Recommended } \\
\text { Plant Community }\end{array}$ \\
\hline$<40$ & 90 & PPW \\
40 to 80 & 310 & NRSF \\
$>80$ & 310 & BF \\
\hline
\end{tabular}

[a] Based on the mean median hydroperiod for each plant community and rounded to the nearest five days. Since differences between NRSF and BF were not significant, data for those communities were pooled to calculate the median hydroperiod for those communities.

southeastern U.S. Coastal Plain but may not apply to other regions. The effects of past agricultural and silvicultural use at a wetland restoration site also need to be considered when selecting an appropriate plant community. For example, the artificial drainage commonly used to convert wetland to agricultural use lowers water levels and may cause organic soils to subside. Ewing and Vepraskas (2006) estimated that in one artificially drained Carolina bay, the organic soil layers subsided approximately $1.2 \mathrm{~m}$ over 15 to 30 years. These changes need to be taken into account when using table 5. In developing these recommendations, we considered the thickness of organic soil layers and the median hydroperiod (total days inundated per year). There are several combinations of organic soil layer thicknesses and hydroperiod that are not addressed in these recommendations. Other factors, such as soil plant-available phosphorus, fire frequency and intensity, and forest stand age, also likely play a role in plant community establishment and are not addressed by this study. These gaps in our recommendations represent opportunities for further research in wetland ecosystem restoration. Studies at other sites, using the methodology presented here, could serve to fill these gaps in the environmental factors that affect the establishment of these and other plant communities.

\section{Summary ANd Conclusions}

When considering the hydrologic characteristics of the plant communities collectively, we concluded that the hydrologic regime of PPW was significantly different from that of NRSF. Hydrology in BF was generally not significantly different from PPW, NRSF, and HP, likely due to the small sample size for BF in this study $(n=2)$. A larger BF sample size would likely reveal significant differences between BF and PPW. Locations supporting HP tended to have a hydrologic regime similar to that of adjacent community types. Based on this observation, and the fact that the HP canopies typically have a low density of short trees (table 1), we theorize that this community is a result of past disturbance (fire, storm damage, logging, etc.). Prior to the disturbance, HP likely resembled adjacent communities. Others have found that PPW could be incorrectly identified as HP in areas damaged by fire (Schafale and Weakley, 1990). Because it is a plant community in transition from a disturbed state, we do not consider HP to be a suitable target for wetland restoration.

Our results provide evidence that hydrologic computer models, when calibrated for site-specific soil and landscape conditions, can be used to effectively quantify and discern differences in the long-term hydrologic regime of wetland plant communities. The hydrologic regime of the PPW plant 
community differed significantly from that of the NRSF, HP, and BF communities. Using these and other environmental data, we demonstrated that recommendations for the restoration of plant communities at a site could be established. While our study investigated a small number of communities in a specific geographical area, this methodology can be further refined and used to quantify the hydrology of other wetland communities, helping others restore the function of these valuable ecosystems.

\section{ACKNOWLEDGEMENTS}

Funding for this research was provided by the North Carolina Department of Transportation (Research Project No. HWY-2004-19) and is gratefully appreciated.

\section{REFERENCES}

Ash, A. N., C. B. McDonald, E. S. Kane, and C. A. Pories. 1983. Natural and modified pocosins: Literature synthesis and management options. Tech. Report FWS/OBS-83/04. Washington, D.C.: U.S. Fish and Wildlife Service.

Beven K. J. 2001. Rainfall-Runoff Modelling: The Primer. Chichester, U.K.: John Wiley and Sons.

Broadhead, R. G., and R. W. Skaggs. 1989. Hydrologic model for the North Carolina peatlands: I. Land and water use. In Agricultural Engineering, 61-70. V. A. Dodd and P. M. Grace, eds. Rotterdam, The Netherlands: Balkema.

Caldwell, P. V., M. J. Vepraskas, R. W. Skaggs, and J. D. Gregory. 2007. Simulating the water budgets of natural Carolina Bay wetlands. Wetlands 27(4): 1112-1123.

Chescheir, G. M., D. M. Amatya, and R. W. Skaggs. 1994. Modeling the hydrology of a natural wetland. ASAE Paper No. 42597. St. Joseph, Mich.: ASAE.

Chescheir, G. M., D. M. Amatya, and R. W. Skaggs. 2008. Hydrology of a natural hardwood forested wetland. In Proc. 13th Annual Intl. Peat Congress: After Wise Use the Future of Peatlands, 468-471. Jyväskylä, Finland: International Peat Society.

Dahl, T. E. 2006. Status and trends of wetlands in the conterminous United States 1998 to 2004. Washington, D.C.: U.S. Fish and Wildlife Service.

Daniels, R. B., S. W. Buol, H. J. Kleiss, and C. A. Ditzler. 1999. Soil systems in North Carolina. Tech. Bulletin 314. Raleigh, N.C.: North Carolina Agricultural Research Service.

DeAngelis, D. L., L. J. Gross, M. A. Huston, W. F. Wolff, D. M. Flemming, E. J. Comiskey, and S. M. Sylvester. 1998. Landscape modeling for Everglades ecosystem restoration. Ecosystems 1(1): 64-75.

Dennison, M. S., and J. A. Schmid. 1997. Wetland Mitigation: Mitigation Banking and Other Strategies for Development and Compliance. Rockville, Md..: Government Institutes, Inc.

De Steven, D., and R. Lowrance. 2011. Agricultural conservation practices and wetland ecosystem services in the wetland-rich Piedmont-Coastal Plain region. Ecol. Applications 21(supp.): S3-S17.

De Steven, D., and M. M. Toner. 2004. Vegetation of upper coastal plain depression wetlands: Environmental templates and wetland dynamics within a landscape framework. Wetlands 24(1): 23-42.

Dimick, B. P., J. M. Stucky, W. Wall, M. J. Vepraskas, T. R. Wentworth, and C. Arellano. 2010. Plant-soil-hydrology relationships in three Carolina bays in Bladen County, North Carolina, USA. Castanaea 75(4): 407-420.

Dobson A. P., A. D. Bradshaw, and A. J. M. Baker. 1997. Hopes for the future: Restoration ecology and conservation biology.

Science 277(5325): 5155-22.
Ewing, J. M. 2003. Characterization of soils in a drained Carolina bay wetland prior to restoration. Unpublished PhD diss. Raleigh, N.C.: North Carolina State University, Department of Soil Science.

Ewing, J. M., and M. J. Vepraskas. 2006. Estimating primary and secondary subsidence in an organic soil 15,20 , and 30 years after drainage. Wetlands 26(1): 119-130.

Ewing, J. M., M. J. Vepraskas, J. G. White, and S. W. Broome. 2011. Changes in wetland soils chemical properties after 15, 20, and 30 years of agricultural production. Geoderma (in review).

Hall, T. F., and W. T. Penfound. 1939. A phytosociological study of a Nyssa biflora consocies in southeastern Louisiana. American Midland Naturalist 22(2): 369-375.

He, X., M. J. Vepraskas, R. W. Skaggs, and D. L. Lindbo. 2002. Adapting a drainage model to simulate water table levels in coastal plain soils. SSSA J. 66(5): 1722-1731.

Johnson, Y. B., T. H. Shear, and A. L. James. 2011. Identifying ecohydrological patterns in natural forested wetlands useful to restoration design. Ecohydrology doi: 10.1002/eco.227.

Kirkman, L. K., P. C. Goebel, L. West, M. B. Drew, and B. J. Palik. 2000. Depressional wetland vegetation types: A question of plant community development. Wetlands 20(2): 373-385.

Klute, A. 1986. Part 1: Water retention: Laboratory methods. In Methods of Soil Analysis, 635-662. 2nd ed. A. Klute, ed. Madison, Wisc.: ASA and SSSA.

Leab, R. J. 1990. Soil survey of Bladen County, North Carolina. Washington, D.C.: USDA-SCS.

Levin, S. A. 1992. The problem of pattern and scale in ecology: The Robert H. MacArthur Award lecture. Ecology 73(6): 19431967.

Luthin, J. N., and D. Kirkham. 1949. A piezometer method for measuring permeability of soil in situ below a water table. Soil Sci. 68: 349-358.

Megonigal, J. P., and F. P. Day. 1992. Effects of flooding on root and shoot production of bald cypress in large experimental enclosures. Ecology 73(4): 1182-1193.

Mitsch W. J., and J. G. Gosselink. 2007. Wetlands. 4th ed. New York, N.Y.: Wiley.

Morgan, K. L., and T. H. Roberts. 2003. Characterization of wetland mitigation projects in Tennessee, USA. Wetlands 23(1): 65-69.

Otte, L. J. 1982. Origin, development, and maintenance of the pocosin wetlands of North Carolina. Report to the North Carolina Natural Heritage Program, Raleigh, N.C.

Richardson, C. J. 2003. Pocosins: Hydrologically isolated or integrated wetlands on the landscape. Wetlands 23(3): 563-576.

SAS. 2008. JMP, Version 8.0. Cary, N.C.: SAS Institute, Inc.

Schafale, M. P., and A. S. Weakley. 1990. Classification of the Natural Communities of North Carolina: Third Approximation. Raleigh, N.C.: .North Carolina Natural Heritage Program.

Schwintzer, C. R., and S. A. Lancelle. 1983. Effect of water table depth on shoot growth, root growth, and nodulation of Myrica gale seedlings. J. Ecol. 71(2): 489-501.

SER. 2004. The SER international primer on ecological restoration. Washington, D.C.: Society for Ecological Restoration International. Available at: www.ser.org/pdf/primer3.pdf. Accessed 1 April 2011.

Sharitz, R. R., and J. W. Gibbons. 1982. The ecology of southeastern shrub bogs (pocosins) and Carolina bays: A community profile. Tech. Report FWS/OBS-82/04. Washington, D.C.: U.S. Fish and Wildlife Service.

Skaggs, R. W. 1978. A water management model for shallow water table soils. Tech. Report 134. Raleigh, N.C.: North Carolina State University, Water Resources Research Institute.

Skaggs, R. W. 1982. Field evaluation of a water management simulation model. Trans. ASAE 25(3): 666-674.

Skaggs, R. W. N. R. Fausey, and B. N. Nolte. 1981. Water management model evaluation for north central Ohio. Trans. $A S A E$ 24(4): 922-928. 
Townsend, P. A. 2001. Relationships between vegetation patterns and hydroperiod on the Roanoke River floodplain, North Carolina. Plant Ecol. 156(1): 43-58.

USDA. 2002a. Wetland Reserve Program: Restoring America's wetlands. Washington, D.C.: USDA Natural Resources Conservation Service.

USDA. 2002b. WETS table documentation. Elizabethtown Lock 2, NC2732. Portland, Ore.: USDA-NRCS Water and Climate
Center. Available at: www.wcc.nrcs.usda.gov/ftpref/support/ climate/wetlands/nc/37017.txt. Accessed 1 April 2011.

Workman, S. R., and R. W. Skaggs. 1989. Comparison of two drainage system models using field data. Trans. ASAE 32(6): 1933-1938.

Zedler, J. B. 2000. Progress in wetland restoration ecology. Trends in Ecol. Evol. 15(10): 402-407. 
